Book Power in Communication, Sociology and Technology

Ed. Angela Repanovici, Manolis Koukourakis, Tereza Khecyoyan

Series: Philosophy, Communication, Media Sciences

Available online at http://trivent-publishing.eu/

\title{
The Journeys of Books
}

\author{
Robert Coravu \\ Department of Communication Sciences, Faculty of Letters, \\ University of Bucharest, Romania, robert.coravu@litere.unibuc.ro
}

\begin{abstract}
The purpose of this essay is to underline the connection between books and travelling, on concrete and metaphorical levels. Travelling is not just the distance between the starting point and the destination. The journey involves a change in the state of the traveller on an emotional, cognitive, and spiritual level. From this perspective, the book is always the fulfilled promise of a journey. It is at the same time the territory and the vehicle of an inner, exploratory travel, and a cultural object that, in order to fulfil its purpose, must walk the way to the reader, its destination. Last, but not least, the book travels over time as a form of recorded memory of mankind.
\end{abstract}

Keywords: role of the book; reading as a journey; mobile libraries; book sharing; ebooks

This is an Open Access article distributed in accordance with the Creative Commons Attribution Non Commercial (CC-BY-NC-ND 4.0) license, which permits others to copy or share the article, provided original work is properly cited and that this is not done for commercial purposes. Users may not remix, transform, or build upon the material and may not distribute the modified material (http:/ / creativecommons.org/ licenses/by-nc/4.0/) 


\title{
The Journeys of Books
}

\author{
Robert Coravu \\ Department of Communication Sciences, Faculty of Letters, \\ University of Bucharest, Romania, robert.coravu@litere.unibuc.ro
}

The traveller goes well with the road

The traveller goes well with the book

The book goes well with the road

\section{The book - a journey per se}

Each book is a journey per se: it takes us from one point of our life experience and carries us to another, where we find ourselves enriched with ideas, stories, knowledge, feelings generated by the experiences and imagination of other people. This journey can be done for leisure, can have an educational goal or can represent a form of resistance, of survival, of escape from an overwhelming reality.

Reading as entertainment is the most usual interaction with the book. Here, a particular case is the book that accompanies the traveller, that is his/her companion. The traveller goes well not only with the road, as one Romanian proverb says, but also with the book. The book which accompanies the traveller is a journey inside another journey, a virtual one added to the one made in the real world.

On the other pole, reading as a way of resistance is a familiar experience, not so distant in time, for Eastern Europe. Before the changes which occurred in this area in 1989, the book was, for the people of these countries, an open door to freedom, one of the few ways to break out of a prison without bars.

Reading is a survival reflex activated in any totalitarian society, even in settings hard to imagine. Most of the Theresienstadt survivors named the access to written word as one of the basic reasons of their survival, reading being, in such an extreme context, "a crucial tool of comfort, learning, and escape." 1 The Ghetto Central Library, inaugurated in August 1942, whose collections included, at the end of the war, around 100,000 volumes, was part of the props of an "exemplary concentration camp" - in fact, a transit point to death camps as Treblinka or Auschwitz - used by the Nazis in order to show to the world that the Jews with a certain social and intellectual status who were "hosted" here lived a normal life. The collections of the Ghetto Central Library came from the Jewish libraries confiscated by the Nazis but also included books found in the luggage of deported Jews. The library had a reading room, some branches and a bookmobile system - boxes with books which travelled around the camp. Thus, in the midst of a tragedy without equivalent in the history of mankind, defying the omnipresent spectre of death, the book had an important contribution to survival by facilitating journeys of the imagination beyond the barbed wire fences.

\footnotetext{
${ }^{1}$ Miriam Intrator, "People were literally starving for any kind of reading: The Theresienstadt Ghetto Central Library, 1942-1945” Library Trends 55, no. 3 (2007): 514.
} 


\section{Travelling books}

Starting from the third library science law of Ranganathan - "Every book its reader" - one can say that the fate of the book is to travel, to come down from the shelf in order to be read, to be borrowed from a library or from one reader to another, to travel sometimes long and difficult roads to get to the one who needs it. The book goes well with the road: an unread book, that lays on a library shelf, does not fulfil its destiny.

For a long time, until the codex imposed itself as the most ergonomic shape of the book-object, the book had a corporality that limited its circulation. The conjunction between the advantages of codex and those of the printing technology facilitated the journeys of the books.

Later on, when book circulation developed in parallel with the preservation as main function of libraries, the journeys of the books were supported by lending services provided inclusively to those readers who were unable or in difficulty to reach the library building. Even before the emergence of modern public libraries, the goal to provide books to those who used to have difficulties to get them was reached through mobile libraries, also known as itinerant libraries or travelling libraries. In 1679, the English reverend Thomas Bray established the first travelling loan libraries in order to help clergymen who did not have the possibility to acquire the theological books they needed. These mobile libraries were constituted from books packed in boxes and sent to the deaneries of British colonies ${ }^{2}$. In Great Britain, the Industrial Revolution and the improved transportation facilitated the emergence, at the beginning of $19^{\text {th }}$ century, of itinerant libraries in the form of collections borrowed by a central library, having as main target the rural population or the people from sparsely populated areas, where the books were transported by ships, trains or horse wagons.

In USA, the person who had the idea of travelling books was the famous Melvil Dewey, in 1893. His initiative was based on the belief that reading is fundamental for progress and started from the remark that many communities did not have financial means for establishing public libraries. Shortly, nearly 30 American states provided, in one form or another, mobile library services. The first bookmobile was launched in 1905, when Washington County Free Library, Maryland sent a horse wagon carrying books to different villages whose inhabitants had limited access to library services; in this way, within the first six months of service more than 1,000 volumes were provided. ${ }^{3}$ The horses proved also useful during the Great Depression, when isolated rural people from Kentucky benefited from The Pack Horse Library initiative, a New Deal program which used horse-riding librarians to deliver books. ${ }^{4}$.

The bookmobiles play even today an important role in the countries with big areas and many small, isolated communities (USA, Canada, Australia), whether under their most familiar presentation - the buses especially designed to carry lending collections - or of the planes used in Alaska as flying libraries. ${ }^{5}$ In other countries, the books are travelling using less modern, but equally efficient means. Thus, in Colombia, in 1990, at the initiative of the Ministry of Culture, mobile libraries using donkeys (biblioburro) were launched to deliver books in the remotest areas of the country. ${ }^{6}$

\footnotetext{
2 Diane Bashaw, "On the Road Again" Children \& Libraries: The Journal of the Association for Library Service to Children 8, no. 1 (2010): 32.

${ }^{3}$ Ibidem.

${ }^{4}$ Eliza McGraw, Horse-Riding Librarians Were the Great Depression's Bookmobiles, http://www.smithsonianmag.com/history/horse-riding-librarians-were-great-depressionbookmobiles-180963786 (accessed December 17, 2017).

${ }^{5}$ Nancy Ferrell, “Alaska's flying library” Library Journal 108, no. 6 (1983): 554-555.

${ }^{6}$ Alberto Manguel, Biblioteca nopții [The Library at Night] (Bucharest: Nemira, 2011), 202.
} 
Outside the libraries, one can discuss about the alternative forms of the journeys of the books, as, for example, book sharing. In recent years, book sharing initiatives such as BookCrossing have become very popular. The philosophy of BookCrossing, synthesised in the saying "if you love your books, let them go," encourages readers to share their books, providing them with an online platform for this. A book registered on the platform receives an unique identifier (BookCrossing ID) thanks to whom the person who put it in circulation after meeting its next reader in a public space, letting it on a park bench, in a bus station, in a café or in a "BookCrossing zone" can follow its journey: one could travel only in a certain region, while another one could cover thousands of kilometres. Currently (December, 2017), there are more than 1.8 million active users and around 12.2 million books travelling throughout 132 countries. $^{8}$

In the journeys of the books, the man himself can play the role of a vehicle, whether we are talking about books that travel with or inside him. At the beginning of $19^{\text {th }}$ century, the Transylvanian peasant Badea Cârțan used to cross the mountains from Romania to Transylvania carrying in his saddlebags books and other publications, many of them forbidden by the Austro-Hungarian rulers, in order to give them to Romanian pupils, students, professors and priests. In the written testimonies regarding the experience of political imprisonment during the communist age, as those included in the work Jurnalul fericirii ("The Happiness Diary") of Nicolae Steinhardt, we find many examples of intellectuals who made the books travel to their cellmates, reproducing them from memory, even if fragmentarily and synthetically. In his dystopian novel Fabrenheit 451, Ray Bradbury imagined a total identification of human beings with the books, in a future society where the books, being considered harmful, are condemned to be burned: in order to save the greatest written works of mankind and to preserve them for next generations, book lovers memorize them integrally, becoming bookmen.

\section{E-books or the virtual journeys of books}

In the digital age, the independence won by the content of the book from its material shape modified the relationship between book, space and time. The journeys of the books are not defined any more through the distance travelled, but through the speed with which they reach the reader, through the number of kilobits per second with which they are transferred to a reading device.

The interaction with an e-book reader or with a tablet, a cell phone or a computer used as reading devices is different from many perspectives. The relationship with the corporality of the printed book is much more intimate, more personal. Each copy of a printed book has its own biography, its own journey in time which defines it, which leaves traces on its body following the wear caused by use and age or in the form of annotations and underlining made by its owner(s); each copy has been bought, has been part of one or many personal or public libraries, perhaps has been passed from one generation to another, being thus a reference for the history of a family. For e-books, the copy is not any more an operational notion, but the loss of the material body makes the reading more ergonomic and allows the storage of large number of books on an easy-to-carry medium.

\footnotetext{
7 Pamela LiCalzi O'Connell, Free Your Books, New York Times (July 18, 2002), http://www.nytimes.com/2002/07/18/technology/online-diary.html (accessed December 17, 2017). 8 About BookCrossing, http://www.bookcrossing.com/about (accessed December 17, 2017).
} 


\section{Conclusions}

Beyond the changed reading habits and relationship with the book, the journeys of the books will continue to accompany the passing through time of human beings. The shape of the book changed in the digital environment, but its substance remains the same. Innovations like the hyperbooks or visual books didn't generate the expected revolution. The Promised Land of the electronic book which provides a different reading experience, based on hypermedia, still waits for its population. Printed or electronic, text-based only or enriched by multimedia, with or without a material body, the book still is the fulfilled promise of a journey.

\section{Note}

A version of this paper was published in Romanian, under the title „Călătoriile cărții” [The journeys of the books], in the volume: Popescu, Cristina (ed.). Călătoria cărții: itinerar prin lumea informației [The journey of the book: itinerary within the world of information]. București: Editura Universității din București, 2016, p. 267-272.

\section{References}

Bashaw, Diane. "On the Road Again." Children \& Libraries: The Journal of the Association for Library Service to Children 8, no. 1 (2010): 32-35.

Ferrell, Nancy. "Alaska's flying library.” Library Journal 108, no. 6 (1983): 554-555.

Harrison, Tanja. "The Courage to Connect: Mary Kinley Ingraham and the Development of Libraries in the Maritimes.” Library \& Information History 28, no. 2 (2012): 75-102.

Intrator, Miriam. "People were literally starving for any kind of reading: The Theresienstadt Ghetto Central Library, 1942-1945." Library Trends 55, no. 3 (2007): 513-522.

Kirby, David. "The Traveling Library." Michigan Quarterly Review 48, no. 4 (Fall 2009). http://hdl.handle.net/2027/spo.act2080.0048.408 (accessed December 17, 2017).

LiCalzi O'Connell, Pamela. "Free Your Books.” New York Times (July 18, 2002). http://www.nytimes.com/2002/07/18/technology/online-diary.html (accessed December 17, 2017).

Manguel, Alberto. Biblioteca nopții [The Library at Night]. Bucharest: Nemira, 2011. 